\title{
Uliginosibacterium gangwonense gen. nov., sp. nov., isolated from a wetland, Yongneup, in Korea
}

Correspondence

Soon-Wo Kwon

swkwon@rda.go.kr

\author{
Hang-Yeon Weon, ${ }^{1}$ Byung-Yong Kim, ${ }^{2}$ Seung-Hee Yoo, ${ }^{2}$ \\ Soon-Wo Kwon, ${ }^{2}$ Seung-Joo $\mathrm{Go}^{2}$ and Erko Stackebrandt ${ }^{3}$
}

\author{
${ }^{1}$ Applied Microbiology Division, National Institute of Agricultural Science and Technology, \\ Rural Development Administration (RDA), Suwon 441-707, Republic of Korea \\ ${ }^{2}$ KACC-Korean Agricultural Culture Collection, Microbial Genetics Division, National Institute of \\ Agricultural Biotechnology, RDA, Suwon 441-707, Republic of Korea \\ ${ }^{3}$ DSMZ-Deutsche Sammlung von Mikroorganismen und Zellkulturen GmbH, Inhoffenstraße 7b, \\ 38124 Braunschweig, Germany
}

\begin{abstract}
A yellow-pigmented, Gram-negative, aerobic bacterial strain, designated $5 \mathrm{YN}^{10}-9^{\top}$, was isolated from a wetland, Yongneup, of the Inje region, Korea. Cells were motile by means of one polar flagellum. Based on $16 \mathrm{~S}$ rRNA gene sequence analyses, strain $5 \mathrm{YN}^{10}-9^{\top}$ was shown to be related to the genera Azoarcus, Azovibrio, Thauera and Zoogloea, showing moderate sequence similarities of 90.2-93.3, 92.7, 90.9-93.3 and 92.4-92.6\% to members of these genera, respectively. Its distinct phylogenetic position and the low $16 \mathrm{~S}$ rRNA gene sequence similarity values toward the closest related genera support the inclusion of this novel isolate in a new genus. The major isoprenoid quinone was ubiquinone $8(\mathrm{Q}-8)$. The predominant cellular fatty acids were $\mathrm{C}_{16: 0}$ and summed feature 3 (comprising $\mathrm{C}_{16: 1} \omega 7 \mathrm{c}$ and/or iso- $\mathrm{C}_{15: 0}$ 2-OH). The DNA G+C content was $59.3 \mathrm{~mol} \%$. The results of phenotypic, chemotaxonomic and phylogenetic analyses indicate that strain 5 YN10-9 $9^{\top}$ represents a novel species of a new genus within the family Rhodocyclaceae, class Betaproteobacteria, for which the name Uliginosibacterium gangwonense gen. nov., sp. nov. is proposed. The type strain is 5 YN10-9 $\left(=\operatorname{KACC} 11603^{\top}=\mathrm{DSM} 18521^{\top}\right)$.
\end{abstract}

Garrity \& Holt (2001) listed five genera, Rhodocyclus, Azoarcus, Propionibacter, Thauera and Zoogloea, within the family Rhodocyclaceae. Since then, many genera, for example Azonexus, Azospira, Azovibrio (Reinhold-Hurek \& Hurek, 2000), Dechloromonas (Achenbach et al. 2001), Ferribacterium (Cummings et al., 1999), Propionivibrio (Brune et al., 2002), Quadricoccus (Maszenan et al., 2002) and Sterolibacterium (Tarlera \& Denner, 2003), have been newly classified within the family Rhodocyclaceae, class Betaproteobacteria (Garrity et al., 2005). The type genus of the family Rhodocyclaceae is Rhodocyclus.

Yongneup $\left(38^{\circ} 12^{\prime} 53^{\prime \prime} \mathrm{N} 128^{\circ} 07^{\prime} 30^{\prime \prime} \mathrm{E}\right)$ is a wetland located at over $1200 \mathrm{~m}$ above sea level and is the only high moor in Korea. Peat layers in the wetland are about $150 \mathrm{~cm}$ thick and have been formed over the past 4000-5000 years.

Wetland peat samples were serially diluted with $0.85 \%$ $\mathrm{NaCl}(\mathrm{w} / \mathrm{v})$ and suitable ten-fold dilutions were plated onto R2A agar (Difco). These plates were incubated at $28{ }^{\circ} \mathrm{C}$ for 4 days. Among the colonies subsequently formed, a yellowcoloured colony was isolated and designated $5 \mathrm{YN} 10-9^{\mathrm{T}}$. This isolate was able to grow on R2A and nutrient agar

The GenBank/EMBL/DDBJ accession number for the 16S rRNA gene sequence of strain 5 YN10-9 ${ }^{\top}$ is DQ665916.
(NA; Difco), but not on trypticase soy agar (TSA; Difco) or MacConkey agar (Difco).

Cell morphology was observed by transmission electron microscopy (912AB; LEO) and phase-contrast microscopy (AXIO; Zeiss) by using cells grown on R2A agar. The $\mathrm{pH}$, temperature and $\mathrm{NaCl}$ ranges for growth were determined by using R2A medium. Strain $5 \mathrm{YN} 10-9^{\mathrm{T}}$ was analysed phenotypically by using the API 20NE, API ZYM and API ID 32 GN systems (bioMérieux) according to the manufacturer's instructions. Gram staining, presence of catalase, oxidase, poly- $\beta$-hydroxybutyrate, and hydrolysis of casein, DNA and starch were determined as described by Smibert \& Krieg (1994). Hydrolysis of carboxymethylcellulose (CM-cellulose; Sigma) $(0.1 \%, \mathrm{w} / \mathrm{v})$, chitin from crab shells $(1 \%, \mathrm{w} / \mathrm{v})$, pectin $(0.5 \%, \mathrm{w} / \mathrm{v})$ and tyrosine $(0.5 \%, \mathrm{w} / \mathrm{v})$ was also tested. Cells of strain $5 \mathrm{YN} 10-9^{\mathrm{T}}$ were Gram-negative, motile by means of a single, polar flagellum, rod-shaped and strictly aerobic (Fig. 1). Table 1 lists the phenotypic differences between strain $5 \mathrm{YN} 10-9^{\mathrm{T}}$ and other closely related genera.

The procedure for identification of isoprenoid quinones followed the HPLC method of Groth et al. (1996). DNA $\mathrm{G}+\mathrm{C}$ content was determined by HPLC analysis of deoxyribonucleosides as described by Mesbah et al. 


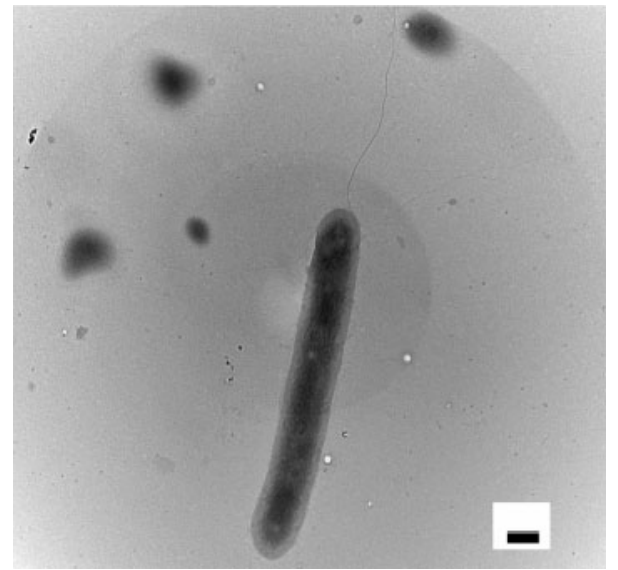

Fig. 1. Transmission electron micrograph of a cell of strain 5 YN10-9 ${ }^{\top}$, showing one polar flagellum. Bar, $500 \mathrm{~nm}$.

(1989), by using a reversed-phase column (Supelcosil LC$18 \mathrm{~S}$; Supelco). Analysis of fatty acid methyl esters was carried out according to the standard protocol of the Sherlock Microbial Identification System (Sasser, 1990). Strain $5 \mathrm{YN} 10-9^{\mathrm{T}}$ had ubiquinone 8 as the predominant isoprenoid quinone. The DNA $\mathrm{G}+\mathrm{C}$ content was $59.3 \mathrm{~mol} \%$. Strain $5 \mathrm{YN} 10-9^{\mathrm{T}}$ contained $\mathrm{C}_{16: 0}(35.2 \%)$ and summed feature 3 (comprising $\mathrm{C}_{16: 1} \omega 7 c$ and/or iso$\mathrm{C}_{15: 0} 2-\mathrm{OH} ; 28.5 \%$ ) as the predominant cellular fatty acids. The following components were also present at $>1 \%$ of the total fatty acids (Table 2 ): $\mathrm{C}_{18: 1} \omega 7 c(7.4 \%)$,
$\mathrm{C}_{17: 0}$ cyclo (5.9\%), $\mathrm{C}_{12: 0}(5.7 \%), \mathrm{C}_{14: 0}(5.4 \%), \mathrm{C}_{12: 0} 3-$ $\mathrm{OH}(4.6 \%), \mathrm{C}_{18: 0}(2.3 \%)$ and summed feature 2 (comprising $\mathrm{C}_{14: 0} 3-\mathrm{OH}$ and/or iso- $\mathrm{C}_{16: 1} \mathrm{I} ; 1.5 \%$ ).

The 16S rRNA gene of strain $5 \mathrm{YN} 10-9^{\mathrm{T}}$ was amplified and sequenced as described by Kwon et al. (2003). This sequence was aligned and compared with those from the GenBank nucleotide database by using an online BLAST search. Phylogenetic trees were inferred by using the neighbour-joining method (Saitou \& Nei, 1987). Evolutionary distance matrices for the neighbour-joining method were generated according to the Kimura twoparameter model (Kimura, 1980). Resultant tree topologies were evaluated by bootstrap analyses (Felsenstein, 1985) based on 1000 resamplings. According to 16S rRNA gene sequence analysis, strain $5 \mathrm{YN} 10-9^{\mathrm{T}}$ was closely related to members of the family Rhodocyclaceae within the class Betaproteobacteria, in particular to members of the genera Azoarcus, Azovibrio, Thauera and Zoogloea (Fig. 2). However, levels of $16 \mathrm{~S}$ rRNA gene sequence similarity towards Azoarcus species (90.2-93.3\%), Azovibrio restrictus LMG $9099^{\mathrm{T}}(92.7 \%)$, Thauera species $(90.9-93.3 \%)$ and Zoogloea species (92.4-92.6\%) were low.

Strain $5 \mathrm{YN} 10-9^{\mathrm{T}}$ could be phenotypically differentiated from members of the above genera based on yellow colony colour, inability to reduce nitrate, ability to hydrolyse urea, differential assimilation patterns and a relatively low DNA $\mathrm{G}+\mathrm{C}$ content (Table 1). Based on comparisons of fatty acid contents, all strains included in the present study contained $\mathrm{C}_{16: 0}$ and summed feature 3 as major components, which was consistent with data from previous

Table 1. Phenotypic comparison of strain $5 \mathrm{YN} 10-9^{\top}$ and closely related genera

Taxa: 1, strain 5YN10-9 ${ }^{\mathrm{T}}$; 2, Azoarcus (data from Garrity et al., 2005); 3, Azovibrio (Garrity et al., 2005; this study); 4, Thauera (Garrity et al., 2005); 5, Zoogloea (Garrity et al., 2005; Xie \& Yokota, 2006). +, Positive result; -, negative result; v, variable among species; ND, not determined.

\begin{tabular}{|c|c|c|c|c|c|}
\hline Characteristic & 1 & 2 & 3 & 4 & 5 \\
\hline Cell width $(\mu \mathrm{m})$ & $0.6-1.0$ & $0.4-1.0$ & $0.6-0.8$ & $0.7-1.0$ & $0.5-1.2$ \\
\hline Colony colour & Yellow & Yellow to beige & Beige & White-yellow & White \\
\hline Nitrate reduction & - & + & - & + & $\mathrm{V}$ \\
\hline Urease & + & ND & $-{ }^{*}$ & - & $\mathrm{V}$ \\
\hline \multicolumn{6}{|l|}{ Assimilation of: } \\
\hline $\mathrm{N}$-Acetylglucosamine & + & ND & $-{ }^{*}$ & ND & ND \\
\hline L-Arabinose & + & $\mathrm{V}$ & $-{ }^{*}$ & $\mathrm{ND}$ & - \\
\hline D-Glucose & + & $\mathrm{V}$ & $-^{*}$ & - & $\mathrm{v}$ \\
\hline 4-Hydroxybenzoic acid & - & + & & + & $\mathrm{v}$ \\
\hline Malic acid & - & $\mathrm{v}$ & $+^{*}$ & - & $\mathrm{v}$ \\
\hline Maltose & + & $\mathrm{V}$ & $-^{*}$ & - & - \\
\hline D-Mannitol & - & ND & $-{ }^{*}$ & ND & - \\
\hline D-Mannose & + & - & $-^{*}$ & $\mathrm{ND}$ & - \\
\hline Phenylacetic acid & - & + & $-{ }^{*}$ & + & $\mathrm{v}$ \\
\hline L-Proline & - & $\mathrm{V}$ & $-^{*}$ & + & ND \\
\hline Propionic acid & - & $\mathrm{V}$ & $+^{*}$ & + & $\mathrm{V}$ \\
\hline DNA G $+C$ content $(\mathrm{mol} \%)$ & 59.3 & $62-68$ & 64.8 & $64-69$ & $67.3-69.0$ \\
\hline
\end{tabular}

${ }^{\star}$ Data from the present study. 
Table 2. Comparison of the fatty acid contents of strain $5 \mathrm{YN} 10-9^{\top}$ and related species

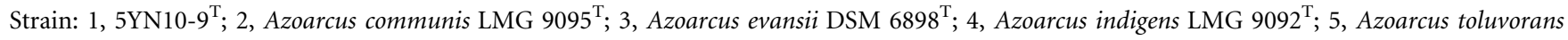
DSM $15124^{\mathrm{T}} ; 6$, Azovibrio restrictus LMG $2218^{\mathrm{T}} ; 7$, Thauera aminoaromatica DSM $14742^{\mathrm{T}} ; 8$, Thauera aromatica DSM $6984^{\mathrm{T}}$; 9 , Thauera chlorobenzoica DSM $18012^{\mathrm{T}} ; 10$, Thauera mechernichensis DSM $12266^{\mathrm{T}} ; 11$, Thauera selenatis ATCC $55363^{\mathrm{T}} ; 12$, Thauera terpenica DSM $12139^{\mathrm{T}}$; 13 , Thauera phenylacetica DSM $14743^{\mathrm{T}} ; 14$, Zoogloea oryzae A-7 ${ }^{\mathrm{T}} ; 15$, Zoogloea ramigera CIP $107119^{\mathrm{T}}$. Data for all strains except Z. oryzae A- $7^{\mathrm{T}}$ (Xie \& Yokota, 2006) were obtained in the present study and cells of these strains were harvested after growth on R2A at $30{ }^{\circ} \mathrm{C}$. Values are percentages of the total fatty acids; - , fatty acids representing $<1.0 \%$ of the total.

\begin{tabular}{|c|c|c|c|c|c|c|c|c|c|c|c|c|c|c|c|}
\hline Fatty acid & 1 & 2 & 3 & 4 & 5 & 6 & 7 & 8 & 9 & 10 & 11 & 12 & 13 & 14 & 15 \\
\hline $\mathrm{C}_{10: 0} 3-\mathrm{OH}$ & - & 6.4 & 7.3 & 6.0 & 6.5 & 7.8 & 6.7 & 12.5 & 8.9 & 4.0 & 6.0 & 19.3 & 8.0 & 2.8 & 4.7 \\
\hline $\mathrm{C}_{12: 0}$ & 5.7 & - & 7.4 & 7.7 & 5.4 & - & 10.1 & 9.7 & 8.7 & 6.4 & 8.0 & 14.3 & 10.2 & 3.1 & 3.0 \\
\hline $\mathrm{C}_{12: 0} 3-\mathrm{OH}$ & 4.6 & - & - & - & - & - & 4.6 & - & - & 2.5 & 3.9 & - & 5.5 & 1.8 & 2.4 \\
\hline $\mathrm{C}_{14: 0}$ & 5.4 & 4.7 & 2.2 & - & - & 3.9 & 1.0 & 1.2 & 1.6 & - & - & 1.1 & 1.2 & - & 2.2 \\
\hline $\mathrm{C}_{17: 0}$ cyclo & 5.9 & - & - & 9.0 & - & - & - & 1.3 & - & - & - & - & - & - & - \\
\hline $\mathrm{C}_{18: 0}$ & 2.3 & - & - & - & - & - & - & - & 2.4 & - & - & 3.1 & - & - & 8.5 \\
\hline $\mathrm{C}_{18: 1} \omega 7 c$ & 7.4 & 9.9 & 1.8 & 8.0 & 11.4 & 11.2 & 5.8 & 9.9 & 12.6 & 13.0 & 11.4 & 5.2 & 9.5 & 2.5 & 12.6 \\
\hline $\mathrm{C}_{18: 1} \omega 9 c$ & - & - & - & - & - & - & - & - & 1.2 & - & - & - & - & - & 2.2 \\
\hline Summed feature $3^{\star}$ & 28.5 & 42.8 & 49.5 & 32.3 & 45.7 & 45.6 & 44.8 & 45.9 & 37.9 & 44.2 & 45.5 & 32.5 & 35.6 & 61.6 & 32.0 \\
\hline
\end{tabular}

${ }^{*}$ Summed feature 3 comprises $\mathrm{C}_{16: 1} \omega 7 c$ and/or iso- $\mathrm{C}_{15: 0} 2-\mathrm{OH}$; summed feature 5 comprises $\mathrm{C}_{18: 2} \omega 6,9 c$ and/or anteiso- $\mathrm{C}_{18: 0}$.

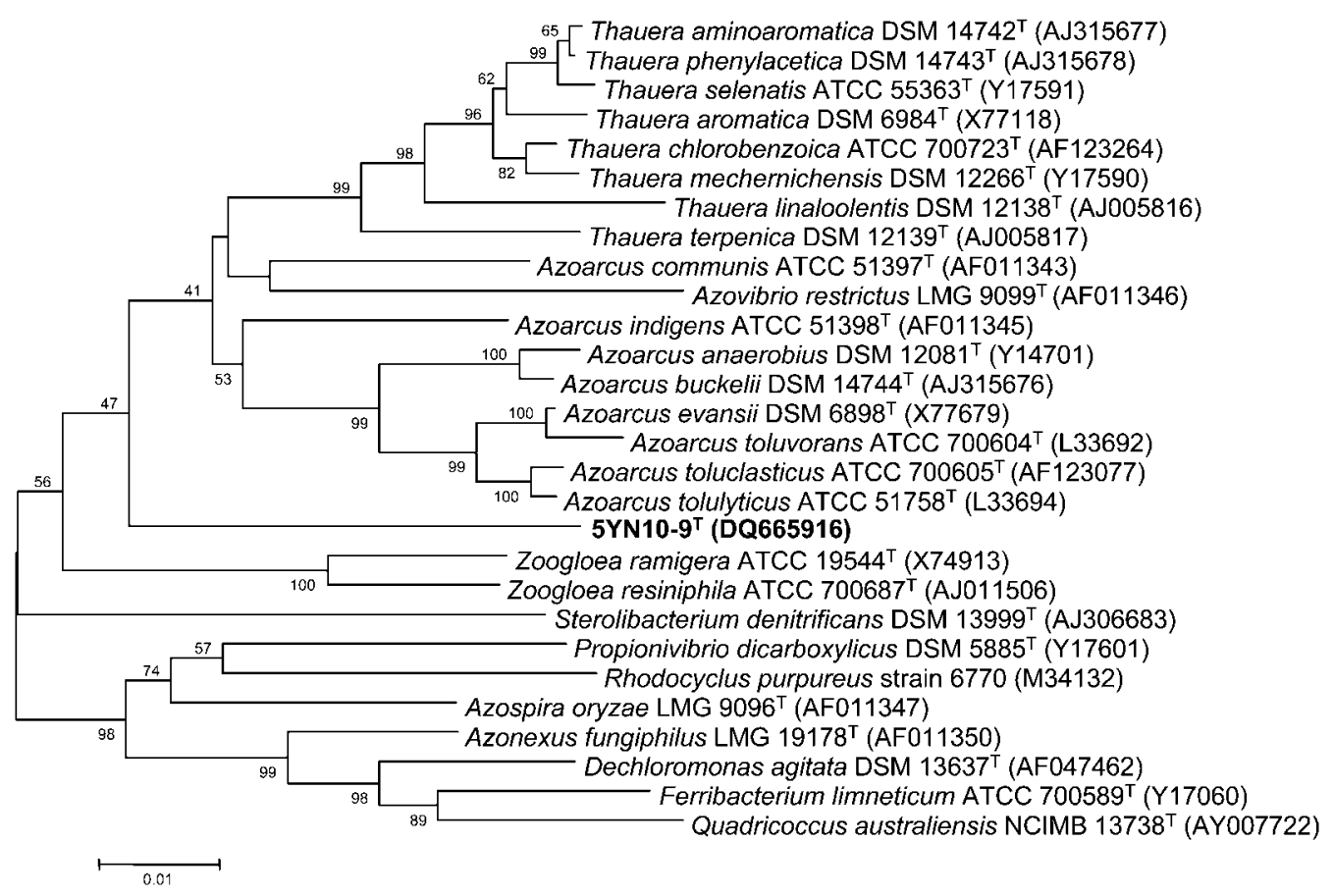

Fig. 2. Neighbour-joining phylogenetic tree derived from analysis of the $16 \mathrm{~S}$ rRNA gene sequences of strain $5 \mathrm{YN} 10-9^{\top}$ and other members of the family Rhodocyclaceae, class Betaproteobacteria. Numbers at nodes indicate levels of bootstrap support based on 1000 resamplings; only values above $40 \%$ are indicated. Bar, 0.01 substitutions per nucleotide position. 
studies (Song et al., 2001; Xie \& Yokota, 2006). However, strain $5 \mathrm{YN} 10-9^{\mathrm{T}}$ was unique in that it lacked $\mathrm{C}_{10: 0} 3-\mathrm{OH}$ and had a low proportion of summed feature 3. $\mathrm{C}_{12: 0} 3-$ $\mathrm{OH}$ was found only in strain $5 \mathrm{YN} 10-9^{\mathrm{T}}$ and members of the genera Thauera and Zoogloea, and $\mathrm{C}_{17: 0}$ cyclo was present only in strain 5YN10-9 ${ }^{\mathrm{T}}$, Azoarcus indigens LMG $9092^{\mathrm{T}}$ and Thauera aromatica DSM $6984^{\mathrm{T}}$ (Table 2). These phenotypic differences were further supported by its phylogenetic position based on 16S rRNA gene sequence data (Fig. 2); the distinct monophyletic line of strain $5 \mathrm{YN} 10-9^{\mathrm{T}}$ and its low $16 \mathrm{~S}$ rRNA gene sequence similarity values with its closest related genera support the inclusion of this isolate in a new genus.

Based on combined phylogenetic and phenotypic data, strain $5 \mathrm{YN} 10-9^{\mathrm{T}}$ is considered to represent a novel species in a new genus, for which the name Uliginosibacterium gangwonense gen. nov., sp. nov. is proposed

\section{Description of Uliginosibacterium gen. nov.}

Uliginosibacterium (Ul.i.gi.no.si.bac.te'ri.um. L. adj. uligonosus wet, moist, marshy; L. neut. n. bacterium a rod; N.L. neut. n. Uliginosibacterium a rod isolated from peat).

Gram-negative, strictly aerobic rods. Motile by means of a single polar flagellum. The major isoprenoid quinone is Q8. The major fatty acids are $\mathrm{C}_{16: 0}$ and summed feature 3 ; $\mathrm{C}_{18: 1} \omega 7 c, \mathrm{C}_{17: 0}$ cyclo, $\mathrm{C}_{12: 0}, \mathrm{C}_{14: 0}$ and $\mathrm{C}_{12: 0} 3-\mathrm{OH}$ are present as minor components. On the basis of the results of $16 \mathrm{~S}$ rRNA gene sequence comparisons, the genus belongs to the family Rhodocyclaceae, class Betaproteobacteria. The type species is Uliginosibacterium gangwonense.

\section{Description of Uliginosibacterium gangwonense sp. nov.}

Uliginosibacterium gangwonense (gang.won.en'se. N.L. neut. adj. gangwonense named after Gangwon Province in Korea, the geographical origin of the type strain of the species).

Has the following characteristics in addition to those given for the genus above. Colonies are irregular and yellowcoloured on R2A agar plates. Cells are $0.6-1.0 \mu \mathrm{m}$ wide and $3.0-7.0 \mu \mathrm{m}$ long. Temperature range for growth is $4-35{ }^{\circ} \mathrm{C}$ (optimum, $25-30{ }^{\circ} \mathrm{C}$ ) and $\mathrm{pH}$ range for growth is $4.0-8.0$ (optimum, $\mathrm{pH}$ 6.0-7.0). Unable to grow in the presence of $2 \% \mathrm{NaCl}$. Catalase- and oxidase-positive. Accumulates poly- $\beta$-hydroxybutyrate. CM-cellulose, starch and Tween 80 are degraded, but casein, chitin, DNA, pectin and tyrosine are not. Positive for urease, aesculin hydrolysis, gelatin hydrolysis and $\beta$-galactosidase, but negative for nitrate reduction, indole production, glucose fermentation and arginine dihydrolase (API 20NE). Positive for esterase (C4), leucine arylamidase, acid phosphatase, naphthol-ASBI-phosphohydrolase, $\beta$-galactosidase, $\alpha$-glucosidase and $\beta$-glucosidase, but negative for alkaline phosphatase, esterase lipase (C8), lipase (C14), valine arylamidase, cystine arylamidase, trypsin, $\alpha$-chymotrypsin, $\alpha$-galactosidase, $\beta$-glucuronidase, $N$-acetyl- $\beta$-glucosaminidase, $\beta$ mannosidase and $\alpha$-fucosidase (API ZYM). Assimilates D-glucose, L-arabinose, D-mannose, $\mathrm{N}$-acetylglucosamine, maltose, sucrose, glycogen and L-serine, but not Dmannitol, potassium gluconate, capric acid, adipic acid, malic acid, trisodium citrate, phenylacetic acid, L-rhamnose, D-ribose, inositol, itaconic acid, suberic acid, sodium malonate, sodium acetate, lactic acid, L-alanine, potassium 5-ketogluconate, 3-hydroxybenzoic acid, salicin, D-melibiose, L-fucose, D-sorbitol, propionic acid, valeric acid, Lhistidine, potassium 2-ketogluconate, 3-hydroxybutyric acid, 4-hydroxybenzoic acid or L-proline (API 20NE and API ID $32 \mathrm{GN}$ ). The DNA G $+\mathrm{C}$ content is $59.3 \mathrm{~mol} \%$.

The type strain, 5YN10-9 $9^{\mathrm{T}} \quad\left(=\right.$ KACC $11603^{\mathrm{T}}=\mathrm{DSM}$ $\left.18521^{\mathrm{T}}\right)$, was isolated from a wetland in Yongneup, Republic of Korea.

\section{Acknowledgements}

This study was supported by the National Institute of Agricultural Biotechnology (NIAB grant no. 06-4-11-19-1), Rural Development Administration, Republic of Korea.

\section{References}

Achenbach, L. A., Michaelidou, U., Bruce, R. A., Fryman, J. \& Coates, J. D. (2001). Dechloromonas agitata gen. nov., sp. nov. and Dechlorosoma suillum gen. nov., sp. nov., two novel environmentally dominant (per)chlorate-reducing bacteria and their phylogenetic position. Int J Syst Evol Microbiol 51, 527-533.

Brune, A., Ludwig, W. \& Schink, B. (2002). Propionivibrio limicola sp. nov., a fermentative bacterium specialized in the degradation of hydroaromatic compounds, reclassification of Propionibacter pelophilus as Propionivibrio pelophilus comb. nov. and amended description of the genus Propionivibrio. Int J Syst Evol Microbiol 52, 441-444.

Cummings, D. E., Caccavo, F., Spring, S. \& Rosenzweig, R. F. (1999). Ferribacterium limneticum, gen. nov., sp. nov., an Fe(III)-reducing microorganism isolated from mining-impacted freshwater lake sediments. Arch Microbiol 171, 183-188.

Felsenstein, J. (1985). Confidence limits on phylogenies: an approach using the bootstrap. Evolution 39, 783-791.

Garrity, G. M. \& Holt, J. G. (2001). The road map to the Manual. In Bergey's Manual of Systematic Bacteriology, 2nd edn, pp. 119-166. Edited by D. R. Boone, R. W. Castenholz \& G. M. Garrity. New York: Springer.

Garrity, G. M., Bell, J. A. \& Lilburn, T. (2005). Family I Rhodocyclaceae fam. nov. In Bergey's Manual of Systematic Bacteriology, 2nd edn, vol. 1, pp. 887-922. Edited by D. J. Brenner, N. R. Krieg, J. T. Staley \& G. M. Garrity. New York: Springer.

Groth, I., Schumann, P., Weiss, N., Martin, K. \& Rainey, F. A. (1996). Agrococcus jenensis gen. nov., sp. nov., a new genus of actinomycetes with diaminobutyric acid in the cell wall. Int J Syst Bacteriol 46, 234-239.

Kimura, M. (1980). A simple method for estimating evolutionary rates of base substitutions through comparative studies of nucleotide sequences. J Mol Evol 16, 111-120.

Kwon, S. W., Kim, J. S., Park, I. C., Yoon, S. H., Park, D. H., Lim, C. K. \& Go, S. J. (2003). Pseudomonas koreensis sp. nov., Pseudomonas 
umsongensis sp. nov. and Pseudomonas jinjuensis sp. nov., novel species from farm soils in Korea. Int J Syst Evol Microbiol 53, 21-27.

Maszenan, A. M., Seviour, R. J., Patel, B. K. C. \& Schumann, P. (2002). Quadricoccus australiensis gen. nov., sp. nov., a $\beta$-proteobacterium from activated sludge biomass. Int J Syst Evol Microbiol 52, 223-228.

Mesbah, M., Premachandran, U. \& Whitman, W. B. (1989). Precise measurement of the $\mathrm{G}+\mathrm{C}$ content of deoxyribonucleic acid by highperformance liquid chromatography. Int J Syst Bacteriol 39, 159-167.

Reinhold-Hurek, B. \& Hurek, T. (2000). Reassessment of the taxonomic structure of the diazotrophic genus Azoarcus sensu lato and description of three new genera and new species, Azovibrio restrictus gen. nov., sp. nov., Azospira oryzae gen. nov., sp. nov. and Azonexus fungiphilus gen. nov., sp. nov. Int J Syst Evol Microbiol 50, 649-659.

Saitou, N. \& Nei, M. (1987). The neighbor-joining method: a new method for reconstructing phylogenetic trees. Mol Biol Evol 4, 406-425.
Sasser, M. (1990). Identification of bacteria by gas chromatography of cellular fatty acids, MIDI Technical Note 101. Newark, DE: MIDI Inc.

Smibert, R. M. \& Krieg, N. R. (1994). Phenotypic characterization. In Methods for General and Molecular Bacteriology, pp. 607-654. Edited by P. Gerhardt, R. G. E. Murray, W. A. Wood \& N. R. Krieg. Washington, DC: American Society for Microbiology.

Song, B., Palleroni, N. J., Kerkhof, L. J. \& Haggblom, M. M. (2001). Characterization of halobenzoate-degrading, denitrifying Azoarcus and Thauera isolates and description of Thauera chlorobenzoica sp. nov. Int J Syst Evol Microbiol 51, 589-602.

Tarlera, S. \& Denner, E. B. M. (2003). Sterolibacterium denitrificans gen. nov., sp. nov., a novel cholesterol-oxidizing, denitrifying member of the $\beta$-Proteobacteria. Int J Syst Evol Microbiol 53, 1085-1091.

Xie, C. H. \& Yokota, A. (2006). Zoogloea oryzae sp. nov., a nitrogenfixing bacterium isolated from rice paddy soil, and reclassification of strain ATCC 19623 as Crabtreella saccharophila gen. nov., sp. nov. Int J Syst Evol Microbiol 56, 619-624. 